\title{
Malay Leadership Pattern in Malaysian Politics
}

\author{
Hailan Salamun \\ Asyraf $\mathrm{Hj} \mathrm{Ab}$. Rahman \\ Hamdan Aziz \\ Rofishah Hj. Rashid \\ Centre for Fundamental and Liberal Education \\ Universiti Malaysia Terengganu \\ and \\ Teachers Education Institute of Malaysia (IPGM) \\ hailan@umt.edu.my \\ asyraf@umt.edu.my \\ hamdan.aziz@umt.edu.my \\ rofishah@ipgm.edu.my
}

This article focuses on Malay leadership practices in Malaysian Politics that display elements of Rabbani leadership in the political workplace. It explores empirical research about the notion of religiosity's spirit, rather than merely individual's bundle of workplace skills and abilities. The results illustrate that Malay political leaders involving in the political activities admit that religious values, or rabbani elements, have had a great impact on their view on leadership practices and political worldview. Potential elements of rabbani leadership derived from the writings of Islamic literature are shaped into a nascent model that serves to both describe leadership perspectives, behaviors, and approaches to followers.

Keywords: Rabbani leadership; Political Leaders; Malay political leadership; political workplace; religious values

\section{Introduction}

The area of the Malay Achipleago is composed of various countries such as Indonesia, Malaysia and Borneo. Malaysia has undergone a wide range of political developments so that there is an orientation based on ethnicity and dominance by the ruling party for a long period of time through total political hegemony. However, sociopolitical scenarios are now seen out of the old cocoon of old politics to the more open and less dominant forms and practices. This scenario leads to hegemonic contra, which is a practice that differs from existing practice.

The shift in the socio-political context of Malaysia turns out to create a new perspective on the practice of political culture in this country. The dominant and regulatory characteristics that have been well-crafted in the form and practice of local cultural politics have been eroded even though not totally. As it turned out, the general election that was held in 2008 has had a tremendous implication on the formation of a new political culture in Malaysia. Hegemony that has been practiced for maintaining the stability of the country and preserving the status quo of the ruling class has become more eroded as the public openly rejects the form of leadership deemed irrelevant in the local sociopolitical leadership discourse. Leadership is an essential feature of all government and governance: weak leadership contributes to government failures, and strong leadership is indispensable if the government is to succeed.

Leadership is a historically concrete phenomenon; that is, its structures and methods change with the passage of time. To influence events and affect outcomes, leaders need to be prepared to abandon policy instruments and ideas that no longer work in a new environment. They need 
to be able to embrace the new and reevaluate the old, even some of the earlier discarded ideas and methods of adapting to environments, if the circumstances call for it (Joseph Masciulli, Mikhail A. Molchanov and W. Andy Knight, 2009). This study examines the relationship between religion and political activity. Mariya Y. Omelicheva \& Ranya Ahmed (2018) asserted the study of religion and politics has emerged as an important area of inquiry in political science and international relations. Religion and politics like as a powerful social force transforming many aspects of national and global politics and shaping individual beliefs and political behaviour. Therefore, the writing of this paper will cover some issues such Islam and Malay in relation to this development seen as a form of contradiction between the practices of today's political openness with the dominant old political elements.

Religiosity, by itself, often serves as an inner factor rather than mobilizing force for political engagement, regardless the denominational differences. Malaysia is a country of various religions and nations such as the Malays, Chinese, Indians and the natives, in practice religious factors do not influence much of the political tendency. According to Tayeb (1997), values, beliefs and life in a society is known as the culture which influence the attitudes and behavior of an individual. Unlike the Malay community whose lives are colored with a culture that has long been affected by the teachings of Islam can influence current political tendencies. The five types of political leadership elements examined in the study include religious worldview understanding, joining in culture of knowledge, participating in community activities, strength in political participation, and social relationship among voters.

The findings in this article are primarily based on fieldwork conducted from 2016 to 2018. To obtain information related to this topic, we conducted in-depth interviews with cadres and party elites at the state and centre levels; with local leaders and scholars in the fives zones, there are; North, West, East, Middle, and Sabah.

\section{Literature review}

\section{Political leaders}

'Political leadership' overlaps significantly with any leaders in any organizational, and is a special part of 'social leadership' in general. Scholars who stress that political leadership is a special part of social science that the concept of leadership is 'related to power: a leader (in the behavioral sense) is a person who is able to modify the course of events' (Joseph Masciulli, Mikhail A. Molchanov and W. Andy Knight, 2009).

It is often said that political leadership need strong influence to their followers. It is necessary for achieving their political destination for the betterment of economic development. Drawing upon relevant theories of political agency, particular attention is given to addressing the relationship between leadership and collective action. According to Mahazan, A. Mutalib and Abdullah, A. Ghani (2014) most scholars have accepted that the major focus of organizational leadership field of study is the process of how a leader 'exerted influence over other people to guide, structure and facilitate activities and relationships in a group or organization. When the term leadership being discussed within the realm of Malaysian politics it reflect the role of political leader is.

Heinz W. Arndt (2011) classified three functions of leadership; there are authority, inspiration and management. It then examines the relevance of political leadership in these three roles to the ends (objectives) and means (strategies) of economic development. Meanwhile Ammeter, A.P. et. al., (2002) politics represent any purposeful attempt to generate or dispose of shared meaning. The term "shared meanings" provide normative guidelines for subsequent behavior and interpretations whereby leaders manage meaning and socially construct reality for themselves and followers. While, the political behavior define as activities designed to 
minimize the vast amount of ambiguity that occurs in organizations, and to give meaning to organizational phenomena where uncertainty exists. He added political leadership is divided into three basic components: a) antecedents of leader political behavior, b) leader political behavior, and c) consequences of political behavior.

Bouzarinejad, Yahya \& Zarpeyma, Shahin \& Marandi, Elahe (2016) quote Sayyid Qutb words that religious and political laws of Islam are not separate from one another. Islamic government and its involvement in all political, social and cultural affairs. Islam is a comprehensive school whose law (Sharia) should be implemented in all facets of Islamic society. Islam as a religion has not only come to crawl in the hearts and temples, and be confined to preach, but the main aim is legislation and the establishment of social and political structures and institutions. Mohd. Kamal Hasan (1982) viewed political leadership have to come up based on the spirit of Islam. Political leaders who work for the establishment of new government phase as a group who get the mandate from God that Muslims need to do to uphold the Shariah of God on earth to achieve the well-being of life in the world and in the hereafter. Islamic political thought in the context of national countries is divided into three, namely: $i$. the effort to build and implement Islamic state, ii. The effort that attempt to combine Islamic ideals with national understanding, and iii. The effort that attempt to combine Islamic concepts with Western ideology, especially socialism and liberalism.

\section{Malay political leadership}

The process of forming a political culture has begun since the era of the Malay Melaka Sultanate. Despite being bound by the tradition and protocols of the relatively strict palace, the people remain obedient and give loyalty which is unwavering to the government. Malay leaders are normally highly respected persons of the community and function in the political institutions. Trust that has been immersed in the emotions and epistemology of the traditional Malay society ultimately giving recognition to the status of the ruling class. The power created in the strata of feudalism created the people's obedience and loyalty towards the Sultanate. The assessment of the sociopolitical situation in Malaysia also shows how the dominance or control of the Barisan Nasional (BN) in the country's political discourse has created a political culture known as hegemony. In the context of political culture in Malaysia, the changes in the era and the phases that have passed have left a huge impact on the social structure of society today (Noor Sulastry Yurni Ahmad, Nor Azila Mohd Azidin, 2013).

Roslan bin Saadon (2007) UMNO is one of the early political organizations that adheres to conservative nationalism. UMNO not only maintains tradition Malay nationality, and even maintaining a tradition of cooperation with the colonial side. The good relationship and the softness of the English administration give much good to UMNO. The greatest privileges are accepted by UMNO is when the British are willing to hold discussions with UMNO and the Malay Rulers in shaping Constitution of the Federation of Malaya. In 1948, when the Emergency Law was implemented, many political organizations were banned but UMNO was allowed to move and this allowed UMNO to become the dominant party and succeeded in controlling the 1955 General Election.

The idea of Malay Raya introduced by the Malay Youth Union (KMM) is a very clear idea of nationalism. The concept of nation-states that is presented is a concept based on the same cultural origins. This ideals are realized in the form of political action. Starting with the Malay Youth Union, it was formed by the Malay National Malay Party (PKMM) and political organizations such as PUTERA-AMCJA, Parti Rakyat Malaya (PRM), Parti Islam Se-Malaya (PAS) and so on.

Unlike UMNO, PAS was trying to show the political holdings of this Nusantara figure based on the spirit of Islam. Although Dr. Burhanuddin al-Helmy as PAS leader is a strong supporter 
of Malay nationalism, but the Malay nationality he holds only as a means of achieving Islamic ideals, as a symbol of attraction and could unite the energy to achieve a noble idea. The relationship between nationalism and the ideals of struggle is likened to a world with the hereafter where the world is not a goal but "only a tool or a ride that convey to the hereafter (Roslan bin Saadon, 2007)

The relationship between the Malay World and the Islamic World is an undeniable fact. Harliana Halim, Kamaruzaman Yusoff, Aminuddin Basir, Shakila Ahmad, and Shamsaadal Sholeh Saad (2013) Islam has introduced a developed concept of civilization of the Malay community. Even the word civilization and manners itself has been introduced by Islam. The introduction of that concept has elevated the Malay community to building a high civilization covering various fields, now and forever. The choice of Islam as the basis of identity is in fact beneficial to the Malay community as it has happened to Arab society. Islam has also raised the dignity of Malay civilization to the international level. This process has led to the spirit of internationalism among Malays within the framework of Tauhid, Ummah, and ukhuwah as the basis in Islamic teaching.

Historians have a view of excellence in the Malay community decision-making scale. The Malay thought has an association with the socialization factor of the community. In addition, the element of progressive among Muslims moderate is also said to be the momentum factor for the paradigm shift in the Malay Archipelago community. Ahmad Murad Merican (2003) Malay thought develops through the network intellectual and heart that encompasses "emotional-intellectual-moral-goodness" in decision-making scale.

The influence of Islamic views is often said to be political Islam by Western scholars has spread widely among the masses in Malaysia in the 1970's. This can be refererred by the development of the distribution of Islamic books from outside either within original form or translation is quite extensive (Rahimin Affandi Abd. Rahim, 2005). The influence of Islam can also be seen to have given birth to some interesting developments involve the existence of intellectual classes Modern Malay Muslims.

However, the political culture that occurred in this era was seen as a new wave by Noor Sulastry Yurni Ahmad, Nor Azila Mohd Azidin (2013). She viewed Malaysian political choices are determined based on material development and individualistic-consumerism. The phenomenon that goes on explains how civil society is no longer practicing adherence to any direction or government requirement, but the obedience to the ruling class is given if their wishes and demands are met. According to Shukri Muhammad Salleh (2012) neo-classical development philosophy as the core of national development being the causes of the imbalance phenomenon of socio-economic development today. Neo-classical defined as the development of methods that are ethnocentric-West, which requires the destruction of communities and cultural traditions for increasing production, income, purchasing power and consumerism as an indicator of development. The effects of a development-ethno-centric West has changed the thinking and culture of Muslims who raced the pursuit of material life when compared to the effort to live the teachings of Islam. In addition, the modern life which had been erode of the faith of Muslims life from preserving the culture and traditions inherited from time immemorial. What is worrying is that the indicators used to some extent succeeded in eroding the morale and confidence of Muslims to live a life based on the Holy Quran and Sunnah, and no longer give priority to culture and tradition of the Malay community.

Islam which has become the "Ad Deen" and also known as the way of life, provides guidance on all matters including the attitude and conduct of a Muslim in his life and in a workplace (Khan, Farooq \& Hussain, 2010; Barhem, Younies \& Muhamad, 2009). Long-Zeng Wu, Ho Kwong Kwan, Frederick Hong-kit Yim, and Randy K. Chiu (2015) Corporate's scandals have widely raised awareness of and attention to ethical issues in business leadership. Workplace 
deviant behavior has becoming more serious among the employees in the organizations today (Sulaiman \& Bhatti, 2013; Omar, Halim, Zainah, Farhadi, Nasir \& Khairuddin, 2011). This deviant behavior is crucial and received critical attention, because it involves economic costs and social costs to the organization and its employees (Kelloway, Francis, Prosser \& Cameron, 2010; Robinson \& Bennett, 1995).

Malaysia, as a developing country cannot get away from the deviant behavior such as embezzlement, abuse of power and corruption which is contrary to morality, ethics and religion and creating socio-economic imbalances and damage the society in Malaysia (Omar et., al., 2011). Among deviant behavior occurred are the issue of integrity (PEMANDU, 2010), misconduct of public employees (Public Complaints Bureau, Prime Minister's Office, 2013), bribery, conflict of interest, using the company's assets as personal use, disclose the information and secret of organizations, theft of money, falsify claim, falsify sick leave, absence from work, stock theft, fraudulent expense claims, theft of physical assets (KPGM, 2013) and corruption (Transparency International, 2012; KPMG, 2013). This workplace deviant behavior is expected to increase in the future, especially when the time of financial crisis.

Islam has rules, guidelines and priorities for the Muslims or the followers which originated from the Quran and the teachings of Prophet Muhammad (s.a.w) (Muhamad \& Ghani, 2006). Religion is the most important values for Muslims because it is the factor that influences the attitudes and behavior of a person (Barhem et al., 2009). Highly religious person will always follow or support his behavior according to the teachings of his religion. However, on the contrary, a person who is considered least religious is not interested in changing the attitude and behavior according to the teachings of his religion (Delener, 1994; Tayeb, 1997; Muhamad \& Ghani, 2006; Mansori 2012).

Islamic work ethics is the requirement of Islam against individuals related to attitudes and behavior in the workplace (Rizk, 2008). Religion affects a person through rules, beliefs, and ways of life and in determining priorities in life (Inglehart \& Baker, 2000). The way of working in Islam is called Islamic work ethic and originated from the Quran, Hadith and the deeds of Prophet Muhammad (s.a.w.) (Kumar \& Che Rose, 2010). Despite the growing problem of the workplace deviant behavior, the government has instilled some of the principle in the country such as the application of Islamic values, Islam Hadhari (Islamic civilization) and Wasatiyyah (Islamic moderation) which emphasizes the importance of religiousness and Islamic work ethics in the job. In Islam, it is importance to look at the job as a devotion and ways of worship (Barhem et al., 2009; Khan et al., 2010).

\section{Rabbani leadership}

To understand political Islamic view is that Islam does not recognize the existence of dualism between the spiritual and the human physical. Islamic government is an important concept in the modern world and political literature that has been established after the death of the Prophet Mohammad (PBUH) in certain historical periods and geographical dimensions in the Muslim world, sometimes as "caliphate" and sometimes in the form of "Imamate"; and it founded its ideological, political, social, and economic principles. The formation of the first Islamic government and its social structures was done particularly by the Prophet Mohammad (PBUH) in Medina, but after his death, various conflicts took place about the succession and caliphate between various Islamic sects, including Sunni and Shia; the consequences of some of these conflicts is still present in the Muslim world (especially after the abolition of the Ottoman caliphate in the important region of Middle East). Bouzarinejad, Yahya \& Zarpeyma, Shahin \& Marandi, Elahe. (2017). 
Rabbani's leadership refers to the leadership that emphasizes shared responsibility and accountability by demonstrating leadership practices that are driven by moral considerations to get the pleasure of Allah swt. Rabbani's leadership practices includes practice Ihsan (devine) in life, capacity building, group collegiality, fostering a culture of knowledge and management of the professional program (Hailan Salamun \& Saeed Shah, 2013).

The sum of the research outlined below is that rabbani leadership in the political workplace is the conscious incorporation of the components of political activities and personal life into a comprehensive approach that fosters continuous growth, improvement, self-awareness, and self-leadership. Political leaders see each follower as a whole person with a variety of skills, knowledge, and abilities that invariably go beyond the narrow confines of political needs. Followers are not cogs in the industrial machine per se. Rather followers are seen as people who not only no-knowing but are not asked to separate their personal life, their core self, from their work, their work skills, or their work goals. There is therefore in this leadership a concern for and integration of the whole-soul, the inner self, of the leader and led. As opposed to perhaps other definitions of leadership, where facts about a leader's personality (trait theory view of leadership) or a leader's behavior in certain situations (behavior theory and situational leadership theory), the core spirit of the leader understood through self-awareness about how one enhances the meaning of and practices within life are most essential. This perspective of leadership suggests that the leader and led do have a clear sense of "religiousity" of self and group members and that sense has a transforming effect on organizations, forms, structures, processes, behavior, and attitudes.

The discussion have been drawn on the issue of Malay political leadership perspectives in the religious and social activities in community. Based on the discussions, we could understand that there were scholars and researchers who called for effective leaders to be positioned in the Malaysian politics.

\section{Finding and Discussion}

\section{A framework of leaders' political Islamic worldview}

Worldview particularly is a philosophy of life or conception of the world. It's the overall perspective from which one sees and interpreted the world. In other hand, it's a collective of belief about life and the universe held by individual or group. Malay political leaders have their own pattern of political Islamic worldview in governance to engage in political behavior and the source of their ability (or lack of ability) to successfully engage in such behavior. Malay leaders especially from PAS (Pan-Islamic Party) and UMNO (United Malays National Organization) has colored the political landscape for a long time until Malaysian $13^{\text {th }}$ general election. However, the leadership of PAS and UMNO faced internal problem which is finally had created new parties such as the AMANAH who was born from PAS leadership, and the PPBM (Malaysian United Indigenous Party) from the UMNO party. AMANAH who bring a moderate Islamic approach and claim the party uphold the voice of 'Rahmatan Lil Alamin' (A mercy to all creation) being a member of new coalition party; The Alliance of Hope (Pakatan Harapan, PH). The coalition was formed on 22 September 2015, consisting of the PPBM (Malaysian United Indigenous Party), PKR (People's Justice Party), and DAP (Democratic Action Party).

UMNO leadership is often advisable to confront the voices that want to be the core of Islamic life when discussed at all times in UMNO general assembly. In issues involving the word Allah for example, UMNO has acted so these issues are addressed properly and it's beneficial to Muslims. Although, the UMNO leadership is not ready to bring the country to a level of creating an Islamic state in which Islamic law implemented in national legislation enforced. 
However, of late, the UMNO leadership often toss ideas that are not contrary to Islam and to link with the implementation of appropriate policy objectives of the syariah.

PAS and UMNO used different approach in support of the struggle of Islam in Malay community. PAS struggle for the benefit to uphold the Islam as the way of life which more inclined to enforce an Islamic state in pursuit of Allah's pleasure with the call of "Allahuakhbar", while UMNO seen more focus to fulfill the need of ummah which in line with objectives of the syariah. UMNO always call the slogan 'lifelong Malays' for the survival of their political domination in the Malay-Muslims community (PAS constitution, amendment 2011; Constitution of UMNO).

In contrast to the PAS leadership articulates a desire in political landscape that this country move towards an Islamic state. In any political talks, PAS leadership was often criticized government measures on the basis of Islam, and recommended Islam to be chosen as the way of life for the muslim community in country or state government. These efforts are to some extent has struck the focus of discussion with the brainstorming idea to the government institutions such as JAKIM, YADIM as well as higher education institutions, and any NGOS like ABIM, JIM, IKRAM, ISMA discussed the structure, characteristics and also the essence of which should be available in a Muslim country. Professionals as well as an ordinary people moved in to jointly participate in any discussions, seminars, discourses that discuss the concept of Islamic' state, contribution of Islamic leaders, as well as the content of teaching the Quran related to political, social and economic in modern society.

PAS, which combines three parties, PAS, IKATAN, BERJASA, over $200 \mathrm{NGOs} \mathrm{and}$ influential figures (NGI) launched a manifesto for the 14th general election with the theme "Malaysia Prosperous: Building a Prosperous State" working together towards a prosperous Malaysia. While Pakatan Harapan (PH) manifesto containing the DAP, PKR, AMANAH and PPBM Parties is embraced through the "Hope for Building a Fulfilling State of Hope" which has 60 commissions initiated with efforts to abolish Goods and Services Tax (GST). There are five main thrusts that relate to alleviating the burden of people's lives, reforming administrative and political institutions, spurring fair and equitable economic growth, restoring the status of Sabah and Sarawak under the 1963 Malaysian agreement and building Malaysia that is inclusive, moderate and glorious in the world.

Here the political Islamic worldview that encompass attempted political influence by the leader, as well as subsequent performance outcomes and target feedback. That is, an episode of leader political influence occurs when the leader directs political behavior towards a target audience, the target responds, and assorted outcomes-including performance-accrue. In an ever-changing political landscape, the political leaders to work to meet the needs of a multiethnic society to address current issues demanding the transparency, integrity and fairness required by today's society. Changes that occur in the process of improvement of life depend on the wisdom of political leaders and leadership effectiveness.

If compared to $\mathrm{BN}$ manifesto, PAS and $\mathrm{PH}$, Pakatan Harapan manifesto is seen more comprehensive especially in worldly life. This is because the manifesto involves all races including Indians specially stated through this manifesto. While the Chinese look at economic opportunities more thoroughly and equitably, especially for all races in Malaysia. PH promised if it was given the opportunity to form the government, the first thing to do was abolish the GST which burdened the people. PH promised to investigate the offenses committed by BN leaders especially through government-led mega projects such as 1MDB's money and promised to bring them which was brought to justice.

\section{Spiritually-oriented political leaders}


The leader political behavior portion of the model discusses in which leaders engage when trying to enact shared meanings with constituencies. Intermediate consequences in the model include target outcomes, that is, target affect and cognitions that result from leader political behavior. Target attitudes and performance are discussed with respect to conditions under which leader behavior will have a positive or negative impact on these important outcomes. Spiritually-oriented political leaders in Malay community are normally highly respected person. Those community leaders, especially Imam or village head is closely related to the tradition of the Islamic community in the country. In some researches, Imam or village head are considered leaders who play important roles in the village community in Malaysia (Rogers, M.L. (1975).

Mahazan, A.M. and Abdullah, A.G. (2014) stressed Malay community religious leaders hold leadership responsibility in the Malaysian Muslim Community. PAS is a political party which offers a package of Malay society and the state in accordance with the requirements of Islam based on the Quran and al-Hadith, as already stated in the party constitution that "Fighting for existence in this country of a society and a government that assimilate values the values of Islam and its laws to please Allah."

Every party's members are recommended to understand the main objective of their involvement in PAS for the sake of the betterment of the Islamic way of life for achieving the pleasure of Allah. The ultimate goal for PAS is putting Islam, the Quran and Sunnah in appropriate place, (Interview of the President PAS Kuala Terengganu). However, efforts to keep religion by UMNO sometimes viewed cynically as not doing enough to confront efforts to make Malaysia as a country that makes the Quran and Hadith as the main reference. UMNO, adopted a common value and a consensus meeting are important to work together in harmony (Interview with Head of Pasir Puteh UMNO).

Meanwhile, UMNO shows some activities by calling to the development of science and culture from the point of ensuring that the spirit of learning among party members and the people who led through courses held, a religious program such as religious speech and religious occasions like birthday of Prophet Muhammad (Interview Umno division head Besut).

There is a tendency when Muslim scholars began to accept ijtihad not made merely to the analysis of text and drawing, but can be extracted based on the objective behind all of the problem faced by the ummah. Emphasizing the efforts to meet the demands of the general objectives of sharia, in addition to monitoring the generation destruction in regulating human needs (Mohammad Hashim Kamali, 2012), considered to be part of the political leadership responsibilities. Juwainy priest, describes the objective of the Imamate is the largest institution to compromise their views, organize the various human needs is a regulation, which has a systems forming life (Mohamad Zaidi Abdul Rahman, 2009)

Whatever the effort and planning done by the government is solely to meet the needs of developing the community. Efforts to create clear administrative policies should be based on Shariah resolutions with the aim of assisting government and leaders in regulating and overseeing communities according to rules that are in line with religious teachings. Even other rules that form the basis for policy-making on behalf of consideration Siyasah Syar'iyyah also stressed the need to take into account aspects related to maslahah according to necessity and particular circumstances, on the basis of whether it serves the public interest of the Muslim community (Ummah).This includes the use of Islamic law, which was not agreed as Istihsan, Sad al-Dharai, Istislah, etc (Mohamad Zaidi Abdul Rahman, 2009).

\section{Islam is the Way of Life}

Malay Muslim's people who tend to live in muslim way will be attracted to any organization or group that is willing to provide enlightenment on the life of Islam as shown during the life 
of Prophet Muhammad s.a.w. This trend can be seen with an increasing number of individuals involved in any organization that is characterized by Islam or Islamic movements like ABIM, JIM, IKRAM, ISMA, TABLIGH, PAS and so on. This trend continued when they were faced with the choice of the political parties contesting in the elections day which could offer an Islamic package of life and in line with the understanding of religious life. Most of them prefer to Malay political leadership to make Islam the way of life and serve as the basis for statehood. PAS struggle to restore Islamic values which characterizing the political struggle could coloring the country's political landscape was evident when PAS was willing to sever ties colleagues in Pakatan Rakyat, namely DAP. PAS believes that those who were involved any political struggle that refuses to uphold God's law is considered contrary to party policy. The effect of this action, resulted in the party facing a leadership crisis that led to the birth of a New Hopes's movement to bring the fight Islam is friendly more with the Malaysia's multi-racial society. In fact, the majority assemblymen won by PAS are shown the area that many school or religious institutions actively developed. There are a lot of Islamic institutions built up in Pangkalan Chepa, such as Maahad, cottages, gallery of Islamic scholars and knowledge centre for the Islamic leader to convey Islamic teaching publicly in Kota Bharu, such as the late Tuan Guru Nik Aziz Bin Nik Mat and other leaders (Interview with the President of PAS Base Chepa).

Whereas for UMNO, the party members who understand better about the important of religion, race and nation are those who are aware of the great responsibility to uphold Malay survival in this country. (Interview Leader Pasir Puteh UMNO Division).'Development' was the main subject being offered to each voter when election season arrives. The voters can clearly distinguish between PAS and UMNO as the political party that offers life forms that will be enjoyed by all voters either 'enhancement of life through the development' or 'life in an Islamic State'. Since UMNO has held the reins of power that can be ruled Malaysia since independence, development enjoyed by Malaysians as a whole can be enjoyed together. However, existing development sometimes cannot be shared across the board, ranging from Malay, Indian, Chinese and indigenous people. In fact, progress in abundance cannot be felt equally in all states of the country. There's more Malays who live below the poverty line in majority number compared to other races. Significant differences in terms of socio-economic development led of ruling parties has been felt that it due to the failure of political leaders who control the government in the Barisan Nasional.

Opposition parties such as PKR, DAP and PAS considers that the lack of political leaders carry out the mandate to manage the development of the country led to fraud, waste, and also the birth of a culture of cronyism. PAS view the key issue was that UMNO did not run a ruling goverment according to Islamic rule by ignoring the guidelines of the Quran and as-Sunnah. Meanwhile, PKR and DAP view the attitude of political leaders of Barisan Nasional headed by UMNO that raced the pursuit of wealth led to leakages of government wealth to be among those involved in the political culture of money and corruption.

After the outcome of the 14th general election announced, Pakatan Harapan made a surprise when it won the majority of the Dewan Rakyat seat and succeeded in forming a government at the Federal level. Pakatan Harapan also managed to seize Kedah, Perak, Negeri Sembilan, Malacca and Johor from the BN and retain Selangor under PKR. In Sabah, ally Pakatan Harapan from the Sabah Warisan party succeeded in forming the state government with Dato 'Seri Shafie Apdal being appointed as the Chief Minister. On the other hand in Kelantan and Terengganu, Pakatan Harapan did not win any seats, and many of his candidates lost their money. In Kelantan, PAS managed to maintain the state government under the party while in Terengganu, PAS succeeded in setting up the state government for the third time after winning over 24 state seats and five parliamentary seats. For BN headed by Dato 'Seri Mohd Najib, this 
defeat was the first time in history that the party only managed to get 79 Dewan Rakyat seats and 166 state seats while retaining Perlis and Pahang under the party. Sarawak does not hold a state election since it was held on May 7, 2016. Pakatan Harapan who used the PKR logo managed to get 113 seats while PAS won 18 seats while the Warisan Sabah won eight seats, Bebas won three seats, and others party got one seat.

\section{Conclusion}

In general, all activities party in PAS, be backed up with the beliefs or reflection on good and bad things based on the Rabbani consideration by chosen Islam as the way of life. Whereas the political leadership in UMNO choose Islam accordance with the modern life. The political leadership in PAS took the opportunity to use the opposition party platform upholding the political awareness among the Muslim community as well as other political leaders and pledged to make Islam the basis for governing the country. Political pressure, as well as nongovernmental organizations who demanded that Islam was supposed to be chosen as best life package could soften the political leadership of the ruling party headed by UMNO to make the government policies based on the objectives of the Syariah Law.

Although, PAS has joined a coalition party, which PKR and DAP also did not make Islam as the core of the political struggle, but PAS leadership strictly wanted Islamic law enforced in the state of Kelantan under state government. Assertiveness of PAS leadership has resulted in the breakup of the coalition party, which DAP ultimately destroyed the 'bonding' of Pakatan Rakyat (PR). This decision is also disliked by some PAS leadership whom labeled as G-18 until they lost to maintain the position of being part of the committee members for Pas center in the conference of 61st PAS. The group of G-18 have supporters from party's grassroots to form group called a 'Movement of New Hopes' to maintain ties coalition of opposition parties, between PKR, DAP and GHB known as PR 2.0. New Hopes movement had been forming the political direction that is based on the struggle to defend the people in the framework of the "Blessings Al-Amin '.

It is a successor to PR that PH, was established in 2015 as an opposition to the formerruling Barisan Nasional (BN). It is the largest bloc in the Dewan Rakyat and is the current ruling party of Malaysia. The coalition is allied with the Sabah Heritage Party (WARISAN) and the United of Pasokmomogun, Kadazandusun, and Murut Organisation (UPKO) in the state of Sabah. At the state level, the coalition is the largest party in 8 of 13 state legislative assemblies and forms the government in the states of Kedah, Penang, Perak, Selangor, Negeri Sembilan, Malacca, Johor and Sabah. PH also form a government with two-thirds majority in the states of Penang, Selangor and Johor.

\section{References}

Ahmad Fauzi Ahmad Zaini, Zulkiflee Daud, and Fais Ahmad. (2016). Preliminary Study On The Effect Of Religiosity And Islamic Work Ethics: Towards Workplace Deviant Behavior Among Muslim Employees. THE INTERNATIONAL JOURNAL OF BUSINESS \& MANAGEMENT.

Ahmad Murad Merican. (2003). Membisu Seribu Bahasa, Mendusta Seribu Kata: Kesedaran Alam Melayu Dalam Kajian Komunikasi Di Malaysia (Membisu Seribu Bahasa, Mendusta Seribu Kata: Awareness Of The Malay World In Communications Studies In Malaysia). MELAYU: JURNAL ANTARABANGSA DUNIA MELAYU, Jilid 6 Bil. 1, p. 81-98 
Ammeter,A.P., Douglas, C., Gardner, W.L., Hochwarter, W.A. and Gerald R Ferris. (2002). Toward A Political Theory Of Leadership. THE LEADERSHIP QUARTERLY.Volume 13, Issue 6, P. 751-796

Abd. Hamid, Mohd. Azhar and Balwi, Mohd. Koharuddin and Othman, Muhamed Fauzi and A. Kassim, Othman (2004) Wajah moral masyarakat Melayu pascamoden: Antara realiti, harapan dan gagasan pendidikan moral tinggi. In: Seminar Antarabangsa Nilai dalam Komuniti Pasca Modenisme (SIVIC 2004), 4-6 September 2004, Hotel City Bayview Langkawi.

Abdullah Sulaiman, Syed Muhammad Dawilah Al-Edrus. (2012). Kitab Jawi Dan Karya Sains: Wacana Ketamadunan Dan Jati Diri Orang Melayu. Journal of Techno Social, issue on society, technology and governance. penerbit.uthm.edu.my > Home > Vol 4, No 2 (2012)89102. Diambil daripada http://penerbit.uthm.edu.my/ojs/index.php/JTS/article/download/ $1432 / 968$

Abdullah Firdaus, Mohd. Nasir Omar \& Idris Zakaria. (2015). Pemikiran Politik Dan Kenegaraan Mohammad Natsir. International Journal of Islamic Thought. Vol. 7: (June). www.ukm.my/ijit.

Bouzarinejad, Yahya \& Zarpeyma, Shahin \& Marandi, Elahe. (2016). Sayyid Qutb and Political Islam: Islamic Government from the Perspective of Sayyid Qutb. Journal of History Culture and Art Research. Vol. 5, No. 4. 92-112.

file:///D:/Users/HP/Downloads/Sayyid_Qutb_and_Political_Islam_Islamic_Government.pdf

Harliana Halim, Kamaruzaman Yusoff, Aminuddin Basir, Shakila Ahmad, Shamsaadal Sholeh Saad. (2013). Pengaruh Islam Dan Anjakan Paradigma Pemikiran Melayu: Satu Tinjauan. JOURNAL OF TECHNO-SOCIAL. Volume 5, No. 2, p. 18-30

Heinz W. Arndt (1984) The Role Of Political Leadership In Economic Development. CANADIAN JOURNAL OF DEVELOPMENT STUDIES. Volume 5- Issue 1, 51-63

Leni Winarni.(2014). The Political Identity Of Ulama In The 2014 Indonesian Presidential Election. Al-Jāmi 'Ah: Journal Of Islamic Studies. Vol. 52, No. 2, Pp. 257-269.

Long-Zeng Wu, Ho Kwong Kwan, Frederick Hong-Kit Yim, Randy K. Chiu, and Xiaogang He Ceo. (2016). Ethical Leadership And Corporate Social Responsibility: A Moderated Mediation Model. Journal of Bussiness Ethics. Vol 4 Issue 8. P. 317-321

Mahazan Abdul Mutalib and Abdullah Abdul Ghani. (2014). Leadership Development Model For Religious Leaders. Kuala Lumpur: IKIM Press.

Mariya Y. Omelicheva \& Ranya Ahmed (2018) Religion and politics: examining the impact of faith on political participation, Religion, State \& Society, 46:1, 425 ,

Masciulli, Joseph \& Molchanov, Mikhail \& Knight, W. (2009). Political Leadership in Context. The Ashgate Research Companion to Political Leadership. The Ashgate research companion to political leadership. England ;Burlington, Ashgate Pub.

Mehdi Faraji. (2013). Review of Kingshuk Chatterjee, 'Ali Shari'ati and the Shaping of Political Islam in Iran. New York: Palgrave Macmillan.

Mohd Kamal Hassan (1982), "Pemikiran Politik Islam" dalam Y. Mansoor Marican (ed.), Dasar Ilmu Politik, Kuala Lumpur: Dewan Bahasa \& Pustaka, h. 111-137. 
Mohamad Abu Bakar. (2003). Kosmologi Melayu Dalam Konteks Kebangkitan Semula Islam Kini: Suatu Refleksi. Jurnal Usuluddin, Bil 18, 199-208

Noor Sulastry Yurni Ahmad, Nor Azila Mohd Azidin. (2013). Transisi Kontra Hegemoni Dalam Budaya Politik Melayu Di Malaysia (The Transition Towards Counter-Hegemony In Malaysian Political Culture). MELAYU: JURNAL ANTARABANGSA DUNIA MELAYU Jilid 6 Bil. 1, p.120-137

Rahimin Affandi Abd. Rahim, Ruzman Md. Nor, Nor Hayati Bt Md Dahlal, Norafifah Abd Hamid. (2013). Islam Dan Kearifan Tempatan Di Alam Melayu: Analisis Kritikal (Islam And Local Wisdom In The Malay World : Critical Analysis) Jati, Volume 18, December 2013, Pp223-245

Rahimin Affandi Abd. Rahim. (2005). Citra Islam Dalam Pembentukan Manusia Melayu Moden Di Malaysia: Suatu Analisa. JURNAL PENGAJIAN MEIAYU, Jilid 15, 19-51.

Roslan Bin Saadon. (2007). Gagasan Nasionalisme Melayu Raya : Pertumbuhan Dan Perkembangannya. Tesis yang tidak diterbitkan. Ijazah Sarjana Sastera, Pulau Pinang: Universiti Sains Malaysia

Rogers, M.L. (1975). Patterns of Leadership in Rural Malay Community. Asian Survey, 15 (5),p.407-421.

Suzainah Rahmat, Zuraidah Ahmad (2012) Pemikiran Dan Kepimpinan Melayu dalam Suhana Mohamed Norhayatie Ramlee Muharratul Sharifah Shaik Alaudeen.Kontemporari Pemikiran Dan Kepimpinan Melayu. 4-16. Diambil daripada http://eprints.utem.edu.my/15735/1/PemikiranMelayu.pdf 